\title{
Supporing Information
}

\section{ZnO nanorods integrated flexible carbon fibers for sweat cortisol detection}

Sekar Madhu, ${ }^{a}$ Allen Joseph Anthuvan, ${ }^{a}$ Sriramprabha Ramasamy, ${ }^{a}$ Pandiaraj Manickam, ${ }^{\mathrm{b}, *}$ Shekhar Bhansali, ${ }^{\mathrm{c}}$ Ponpandian Nagamony, ${ }^{\mathrm{a}}$ Viswanathan Chinnuswamy ${ }^{\mathrm{a}, *}$

a Department of Nanoscience and Technology, Bharathiar University, Coimbatore 641046, Tamil Nadu, India

${ }^{b}$ Electrodics and Electrocatalysis Division, CSIR-Central Electrochemical Research Institute, Karaikudi 630006, Tamil Nadu, India

c Bio-MEMS and Microsystems Laboratory, Department of Electrical and Computer Engineering, Florida International University, Miami, Florida 33199, USA.

* E-mail: viswanathan@ buc.edu.in. Tel: (+91) 422-2428422.

*. E-mail: pandiaraj@ cecri.res.in. Tel: (+91) 4565-241367.

Cell viability assay. An in-vitro cytotoxicity test was performed as per ISO 10933:5. The fibroblast L929 cells were procured from National Center for Cell Lines (NCCS) and the culture medium was replaced using fresh minimum essential medium (MEM). The cells were seeded at a concentration of $2 \times 10^{5}$ cells per well in $200 \mu \mathrm{L}$ of MEM supplemented with $10 \%$ FBS and allowed to attach for $4 \mathrm{hrs}$ in $5 \% \mathrm{CO}_{2}$ incubator. The test samples were then placed in the cell culture media using a sterile forceps and further incubated for 24 hrs. Following this, $200 \mu \mathrm{L}$ of 3,-4,5 dimethylthiazol-2,5 diphenyl tetrazolium bromide (MTT) $(1 \mathrm{mg} / \mathrm{mL})$ were slowly added in all the wells and incubated at $37{ }^{\circ} \mathrm{C}$ for $4 \mathrm{hrs}$. DMSO was added into the wells and the absorbance was measured at $570 \mathrm{~nm}$ using Biotek multi-mode plate reader. All the measurements were performed in triplicates. The resultant cell viability was calculated using the following formula

$$
\text { Cell viability }=(\text { Treated } / \text { Control }) * 100
$$

The means of the treatment group was compared to the negative control using analysis of variance (ANOVA) followed by Dunnett's test. Data represented as mean \pm standard deviation (S.D) and a probability level of $\mathrm{P}<0.01$ were considered as statically significant. Data plotting and line fitting were carried out by Origin Pro-8 (Origin Lab, Northampton, MA, USA). 
Possible growth mechanism of ZnONRs on CCY. Although the growth of ZnONRs on different substrates have been reported earlier, this is the first report on growing ZnONRs on a CCY using the sputtering technique. The ZnONRs are polar crystals whose positive polar plane are rich in $\mathrm{Zn}$ and the negative polar plane are rich in O. Several growth mechanisms have been proposed for aqueous chemical solution deposition. The most important growth route of a single crystal is the so-called Ostwald ripening process. ${ }^{1}$

$$
\begin{array}{lr}
\mathrm{Zn}\left(\mathrm{NO}_{3}\right)_{2} \rightarrow \mathrm{Zn}^{2+}+2 \mathrm{NO}_{3}^{-} & ------ \text {(eqs. S1) } \\
\left(\mathrm{CH}_{2}\right)_{6} \mathrm{~N}_{4}+6 \mathrm{H}_{2} \mathrm{O} \rightarrow \quad 6 \mathrm{HCHO}+4 \mathrm{NH}_{3} & ------- \text { eqs. S2) } \\
\mathrm{NH}_{4} \mathrm{OH} \leftrightarrow \quad \mathrm{NH}_{3}+\mathrm{H}_{2} \mathrm{O} & ----- \text { (eqs. S3) } \\
\mathrm{Zn}^{2+}+4 \mathrm{NH}_{3} \leftrightarrow \mathrm{Zn}\left[\left(\mathrm{NH}_{3}\right)_{4}\right]^{2+} & ------ \text { (eqs. S4) } \\
2 \mathrm{H}_{2} \mathrm{O} \leftrightarrow \mathrm{H}_{3} \mathrm{O}+\mathrm{OH}^{-} & ------ \text {(eqs. S5) } \\
\mathrm{Zn}^{2+}+2 \mathrm{OH}^{-} \leftrightarrow \mathrm{Zn}(\mathrm{OH})_{2} & ------ \text { (eqs. S6) } \\
\mathrm{Zn}(\mathrm{OH})_{2} \rightarrow \mathrm{ZnO}+\mathrm{H}_{2} \mathrm{O} & ------ \text { (eqs. S7) }
\end{array}
$$

The aqueous solutions of zinc nitrate and HMTA can produce the following chemical reactions (Eq. S1 to Eq. S7). The concentration of HMTA plays a vital role in the formation of $\mathrm{ZnO}$ nanostructure since $\mathrm{OH}^{-}$is strongly related to the reaction that produces nanostructures. Initially, due to decomposition of zinc nitrate hexahydrate and HMTA at an elevated temperature, $\mathrm{OH}^{-}$was introduced in $\mathrm{Zn}^{2+}$ aqueous solution. The separated colloidal $\mathrm{Zn}(\mathrm{OH})_{2}$ clusters in solution will act partly as nuclei for the growth of ZnONRs. During the hydrothermal growth process, the $\mathrm{Zn}(\mathrm{OH})_{2}$ dissolves with increasing temperature. When the concentrations of $\mathrm{Zn}^{2+}$ and $\mathrm{OH}^{-}$reach the critical value in the supersaturated solution, the nucleation begins to form $\mathrm{ZnO}$ nuclei spontaneously in the aqueous complex solution. Afterward, the $\mathrm{ZnO}$ nanoparticles combined together to reduce the interfacial free energy. This is because the molecules at the surface are energetically less stable than the ones already well ordered and packed in the interior. Since the $\left\{\begin{array}{ll}0 & 01\end{array}\right\}$ face has higher symmetry $\left(\mathrm{C}_{60}\right)$ than the other faces growing along the $+c$ - axis $\left(\begin{array}{lll}0 & 0 & 01\end{array}\right)$ direction $)$, it is the typical growth plane. As time increased, new crystal nuclei formed ZnONRs on the CCY. It is concluded that the growth habit is determined by thermodynamic factor and concentration of $\mathrm{OH}^{-}$ions as the kinetic factor in aqueous solution growth..$^{2,3}$ 


\section{FI-IR spectra of CCY and ZnO NRs/CCY}

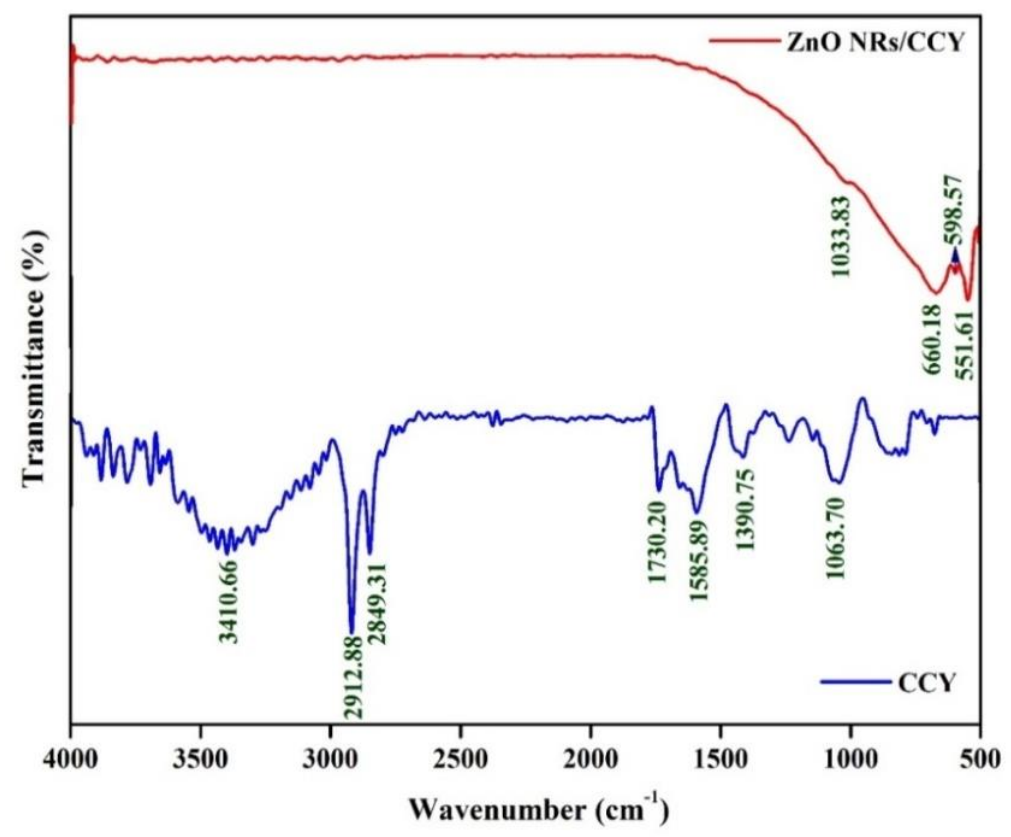

Figure. S1. FTIR spectra of CCY and ZnO NRs/CCY.

Figure. S1 shows the FTIR spectra of CCY and ZnONRs/CCY. The CCY exhibited two peaks at 2917 and $2848 \mathrm{~cm}^{-1}$ were attributed to the $\mathrm{CH}_{2}$ asymmetric and symmetric stretching vibrations, respectively. A strong peak at $1410 \mathrm{~cm}^{-1}$ corresponded to the $\mathrm{C}-\mathrm{C}$ bond stretching. A characteristic peak at $1585 \mathrm{~cm}^{-1}$ represented the $\mathrm{C}=\mathrm{C}$ stretching. The $\mathrm{C}-\mathrm{O}$ stretching vibration was observed at $1063 \mathrm{~cm}^{-1}$ and the peak at $1730 \mathrm{~cm}^{-1}$ was attributed to the $\mathrm{C}=\mathrm{O}$ stretching. The broad peak at $3440 \mathrm{~cm}^{-1}$ was assigned to the $-\mathrm{OH}$ stretching vibration due to absorbed moisture. ${ }^{4}$ In the case of $\mathrm{ZnONRs/CCY}$, in addition to the CCY peaks, the peaks observed at $550 \mathrm{~cm}^{-1}$ and $637 \mathrm{~cm}^{-1}$ were the characteristic vibration modes of $\mathrm{Zn}-\mathrm{OH}$ and $\mathrm{Zn}-\mathrm{O}$, respectively. After the integration of $\mathrm{ZnO}$ on $\mathrm{CCY}$, the peak intensities of CCY were decreased and this may be due to the dense and uniform coating of ZnONRs on the CCY surface. ${ }^{5,6}$

EDS spectra of CCY and ZnONRs/CCY. The EDS analysis of bare CCY was also performed and the results are compared to the ZnONRs integrated CCY (Figure. S2). For bare CCY, the percentage of carbon was found to be $98.77 \%$ whereas, in the ZnONRs integrated $\mathrm{CCY}$, the carbon weight percentage was $8.84 \%$. 

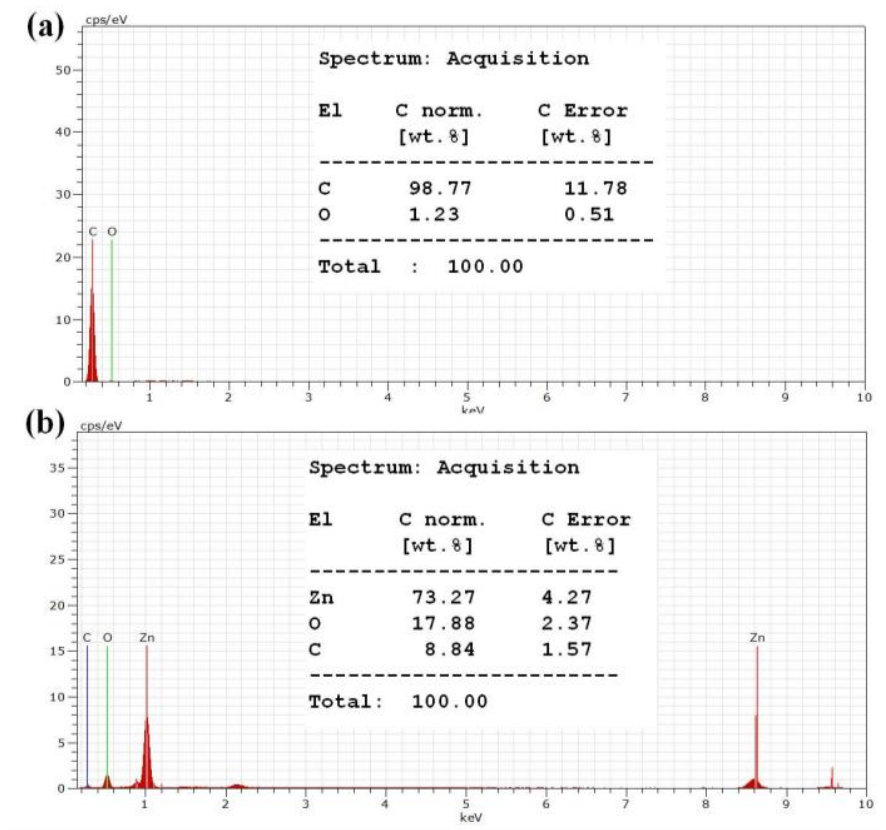

Figure. S2. EDS spectra of (a) bare and (b) ZnONRs integrated CCY.

The results confirmed that the percentage of carbon was decreased due to the uniform growth of $\mathrm{ZnONRs}$ on the CCY surface.

\section{Electrical properties of CCY and ZnONRs/CCY}
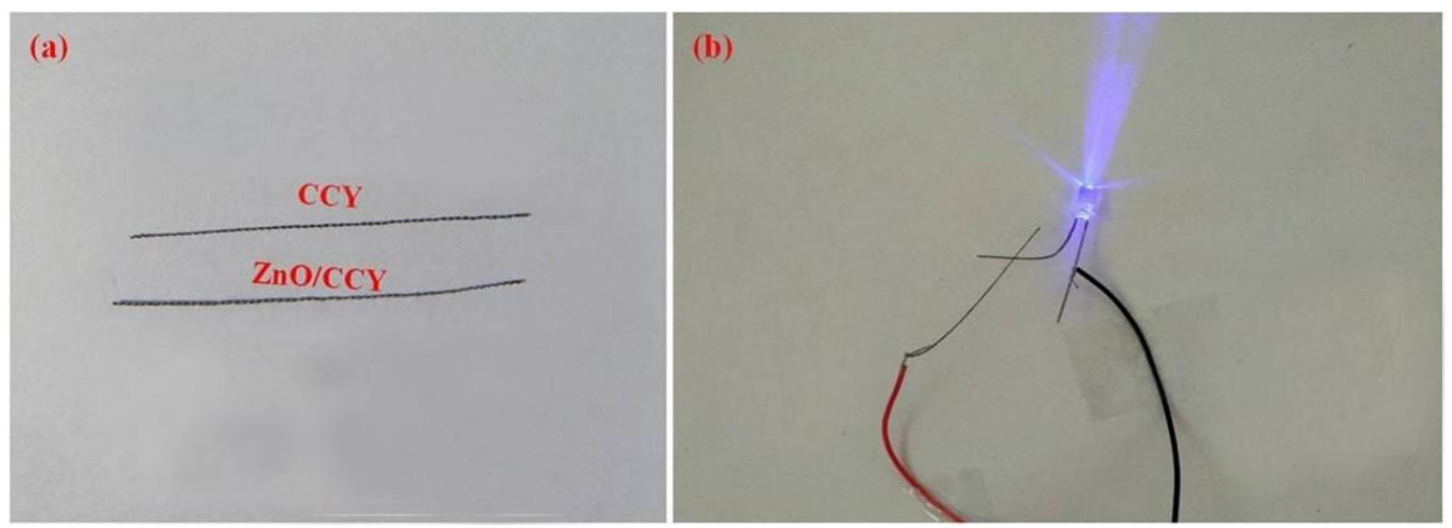

Figure. S3. Photographs of CCY-ZnONRs/CCY; (a) Comparison of the pure CCY and ZnONRs/CCY. (b) Demonstration of LED emission with the current passing through ZnONRs coated CCY.

In order to investigate the electrical properties, the electrical resistivity of $5 \mathrm{~cm}$ long $\mathrm{CCY}$ and ZnONRs anchored CCY was measured. The resistance of the ZnONRs/CCY $(54.3 \pm 1.2 \Omega)$ increased when compared to the bare CCY $(36 \pm 1 \Omega)$. The conductivity of the ZnONRs/CCY wa s demonstrated by powering an LED device connected to a battery as shown in Figure. S3. The amount of ZnONRs deposited on the CCY was calculated to be $\sim 1.5 \mathrm{mg}$ for a $5 \mathrm{~cm}$ length of CCY. 
Active surface area calculation. The high specific surface area of ZnONRs on CCY is beneficial in immobilizing a large number of antibodies to improve the sensitivity of the sensor. Also, from the simple reversible redox system, the accessible surface area $\left(A_{e}\right)$ value was calculated using the Randle-Sevcik equation as given below (Eq. S8). ${ }^{7}$ A uniform fiber length of $5 \mathrm{~cm}$ was maintained throughout the experiments. Approximately $4 \mathrm{~cm}$ length fiber was soaked into the electrolyte solution. Resistive epoxy was coated onto the fiber electrode to minimize wicking and to control the surface area of the fiber.

$$
i_{p}=0.4463 n F A_{e} C \sqrt{\left(\frac{n F v D}{R T}\right)} \quad-------\quad \text { (Eq.S8) }
$$

Where,

$\mathrm{i}_{\mathrm{p}}=$ current maximum in amps; $\mathrm{n}$ is the number of electrons involved in the redox reaction; $\mathrm{F}=$ Faraday Constant in $\mathrm{C} \mathrm{mol}^{-1} ; \mathrm{A}=$ electrode area in $\mathrm{cm}^{2} ; \mathrm{D}$ is the diffusion coefficient $\left(7.6 \times 10^{-6} \mathrm{~cm}^{2} \mathrm{~s}^{-1}\right), \mathrm{C}$ is the concentration of the redox couple; $v=$ scan rate in $\mathrm{mV} / \mathrm{s} ; \mathrm{R}=$ gas constant in $\mathrm{J} \mathrm{K}^{-1} \mathrm{M}^{-1}$; $\mathrm{T}=$ Temperature in $\mathrm{K}$.

\section{Optimization of Anti- $\mathrm{C}_{\text {mab }}$ concentration onto $\mathrm{ZnONRs/CCY} \mathrm{for} \mathrm{immobilization}$}

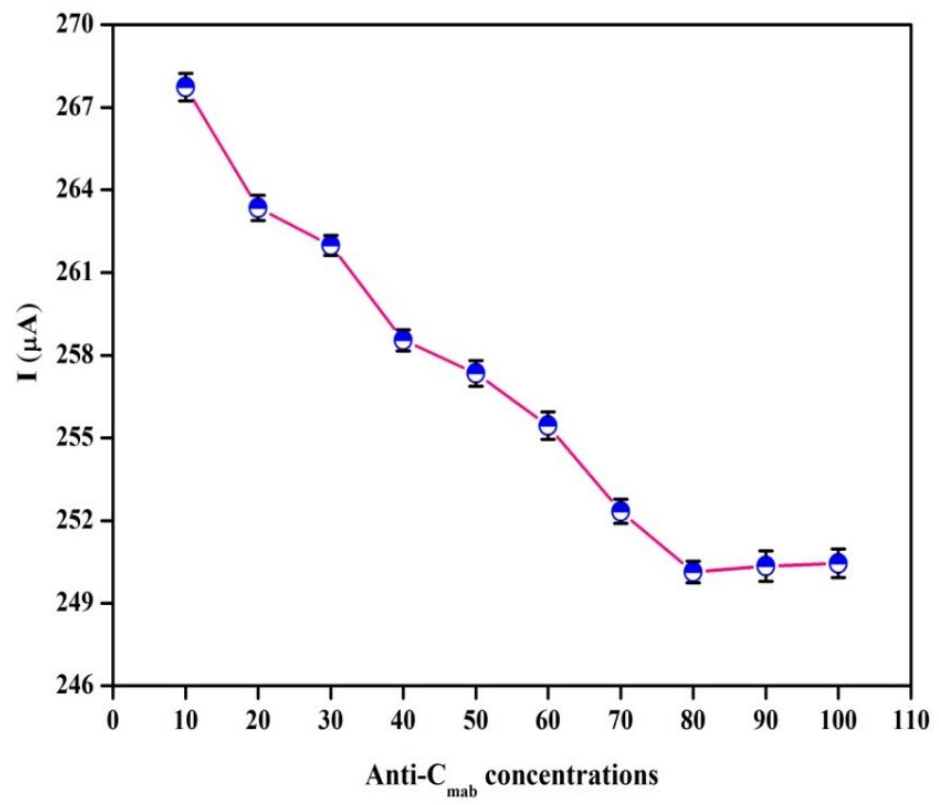

Figure. S4. Optimization of Anti- $\mathrm{C}_{\mathrm{mab}}$ concentrations used for the immobilization of Anti- $\mathrm{C}_{\mathrm{mab}}$ on $\mathrm{ZnONRs/CCY}$ surface.

Optimizing the concentration of cortisol antibodies (Anti- $\mathrm{C}_{\mathrm{mab}}$ ) used for immunosensor fabrication was studied using CV technique. ZnONRs integrated CCY were incubated (for $120 \mathrm{~min}$ ) with series of Anti- $\mathrm{C}_{\mathrm{mab}}$ concentrations ranging from 10 to 100 
$\mu \mathrm{g} / \mathrm{mL}$ in PBS (10 mM, pH 7.0) and the corresponding current responses were measured in the presence of $5 \mathrm{mM}\left[\mathrm{Fe}(\mathrm{CN}) 6^{3-14-}\right]$ redox probe. The current responses observed for the $\mathrm{ZnONRs/CCY}$ were decreased gradually with the increase in concentrations of Anti-Cmab (10 to $80 \mu \mathrm{g} / \mathrm{mL}$ ), indicating that the antibodies are attached to the electrode surface and forming an insulating layer which in turn blocks the electron transfer between the redox probe and electrode. No further significant changes in current response was observed when the the concentration of Anti- $\mathrm{C}_{\text {mab }}$ was increased from 90 and $100 \mu \mathrm{g} / \mathrm{mL}$ as shown in Fig. S4. This can be attributed to the complete coverage of Anti-Cmab onto the $\mathrm{ZnONRs/CCY}$

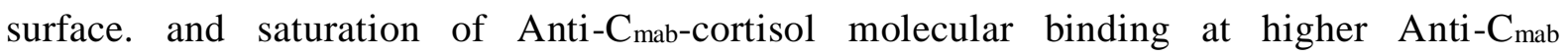
concentrations. Therefore, the optimized concentration of Anti- $\mathrm{C}_{\mathrm{mab}}(80 \mu \mathrm{g} / \mathrm{mL})$ was used for further studies.

pH Effect. The $\mathrm{pH}$ of the buffer medium plays an important role in tuning the sensitivity of the immunosensors as the solution $\mathrm{pH}$ could affect the binding affinity of the antibody. The highest association constants of the antigen-antibody binding were usually obtained in the $\mathrm{pH}$ range 6.0 to 8.4 and considerably reduced above and below the $\mathrm{pH}$ values. The affinity of antibody towards antigen was also influenced by the immobilization protocol and electrode microenvironment. The relationship between the binding affinities of BSA/Anti$\mathrm{C}_{\mathrm{mab}} / \mathrm{ZnONR} / \mathrm{CCY}$ immunoelectrodes toward cortisol as a function of $\mathrm{pH}$ (4.5-8.5) was investigated.
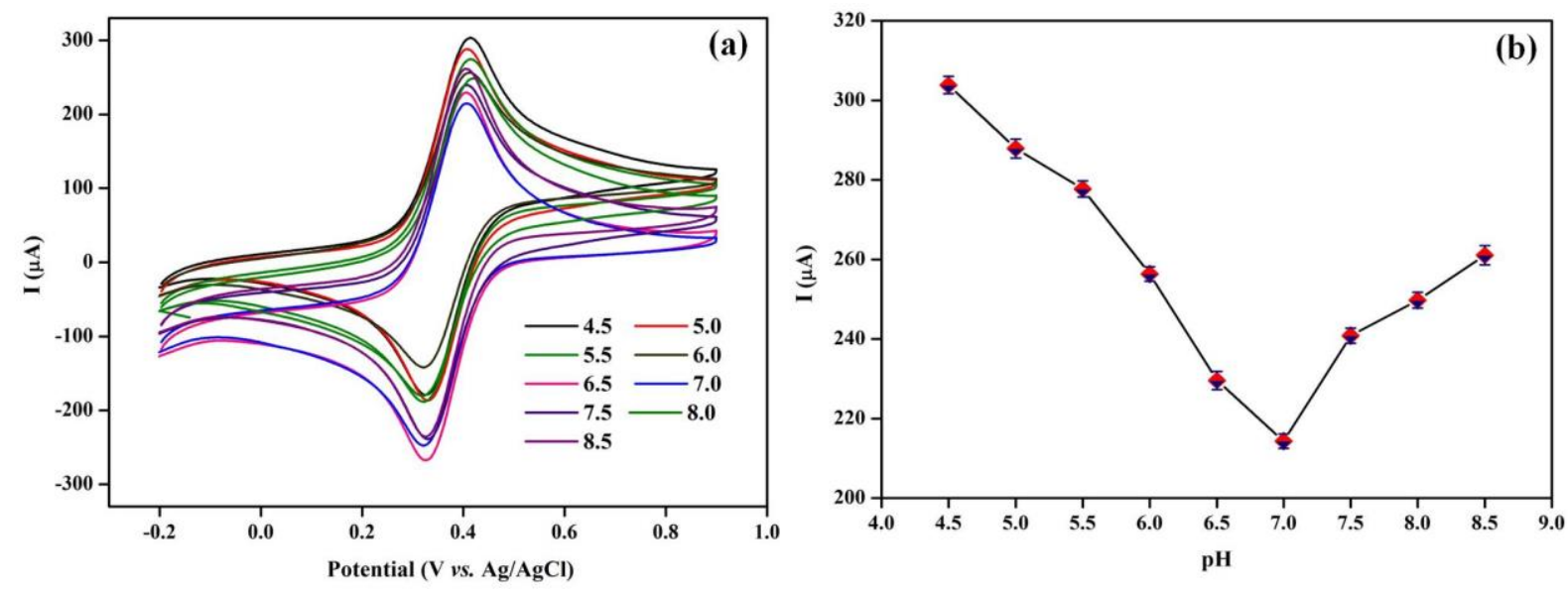

Figure. S5. (a) $\mathrm{CV}$ analysis of the BSA/Anti- $\mathrm{C}_{\mathrm{mab}} / \mathrm{ZnONRs} / \mathrm{CCY}$ immunoelectrode in 10 $\mathrm{mM}$ PBS buffer as a function of $\mathrm{pH}$ from 4.5 to 8.5. (b) Linear plot of peak current vs. $\mathrm{pH}$ values.

It was observed (Figure. S5 (a),) that the magnitude of the oxidation and reduction peak current decreased while increasing the $\mathrm{pH}$ from 6.0 - 7.0. Beyond the $\mathrm{pH} 7.0$, the peak 
current again linearly increased (as shown in Figure. S5(b)) up to $\mathrm{pH}$ 8.5. The lowest and stable redox peak current was observed at $\mathrm{pH} 7.0$, indicating the effective antigen-antibody binding at the particular $\mathrm{pH}$. Thus, $\mathrm{pH} 7.0$ was selected as the working electrolyte $\mathrm{pH}$, which mimics biological conditions.

\section{Electrochemical impedance spectroscopy (EIS) studies towards cortisol detection}

Characterization of step-wise fabrication of immunosensor using EIS. This $R_{c t}$ values measured from EIS analysis provides the information about the degree of surface coverage of antibody and hindrance of charge transfer at the electrolyte/electrode interface The $R_{c t}$ value of bare CCY electrode was found to be $17.24 \Omega$ and upon integration with ZnONRs, the $\mathrm{R}_{\mathrm{ct}}$ value increased to $31.87 \Omega$. The immobilization of the antibody further increased the interfacial resistance values to $45.37 \Omega$, which may be attributed due to the non-conducting nature of Anti-C $\mathrm{C}_{\text {mab }}$ that resists the charge transfer from solution to the electrode.

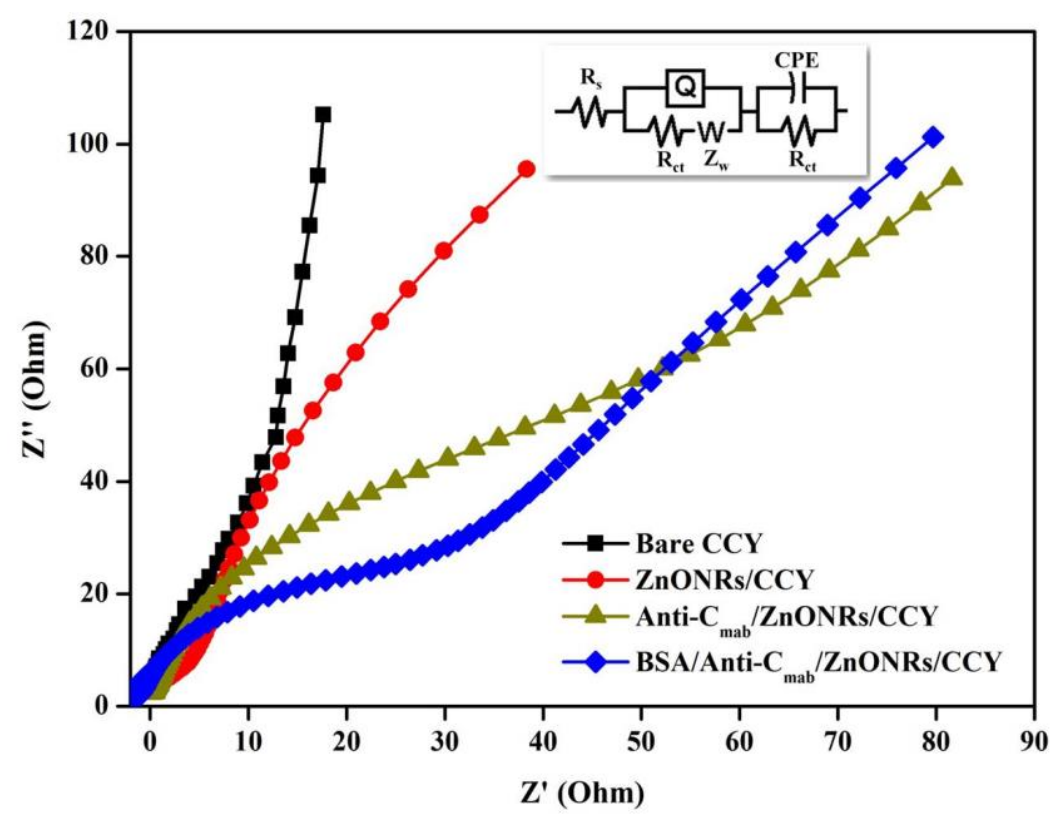

Figure. S6. Nyquist plots related to the stepwise fabrication of ZnONRs based electrochemical immunosensor using EIS in $0.1 \mathrm{M} \mathrm{KCl}$ containing $5 \mathrm{mM}[\mathrm{Fe}(\mathrm{CN})] 6^{3-14-}$. Inset: corresponding equivalent circuit diagram.

Blocking of non-binding sites of antibody on the electrode surface with BSA resulted in higher $R_{c t}$ value $(51.18 \Omega)$. This confirms the successful immobilization of antibodies and BSA onto the ZnONRs/CCY electrode. We have further analyzed the antibody-cortisol binding interaction using EIS analysis and the results are discussed below in detail. 
Cortisol response EIS studies of $\mathrm{BSA} / \mathrm{Anti}-\mathrm{C}_{\mathrm{mab}} / \mathrm{ZnONRs} / \mathrm{CCY}$ immunoelectrode. EIS measurements were conducted to monitor the changes in the charge transport property of the CCY electrodes during each step of modification. Figure. S6 shows the EIS spectra in the form of Nyquist plots observed for the CCY electrodes before and after the immobilization of anti-cortisol antibody and BSA. The diameter of the semicircle portion in the Nyquist plot represents the interfacial charge transfer resistance $\left(\mathrm{R}_{\mathrm{ct}}\right)$ of the electrode surface in the electrolyte.
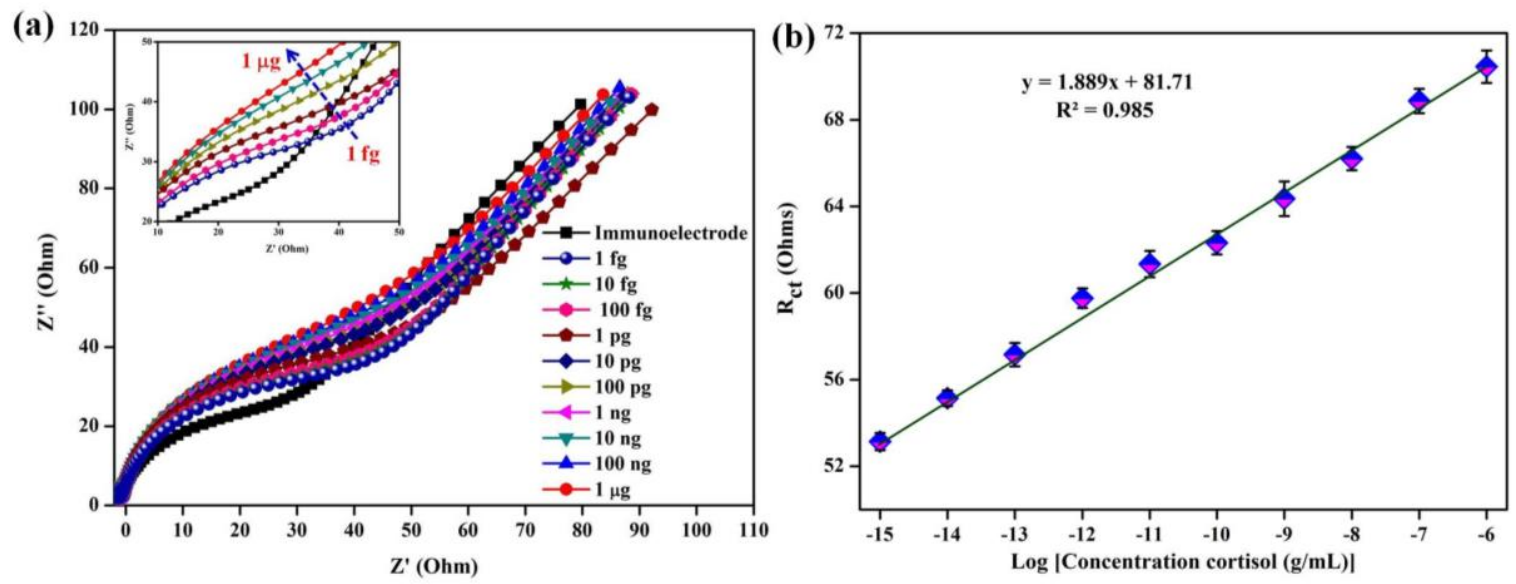

Figure. S7. (a) EIS analyses of BSA/Anti- $\mathrm{C}_{\mathrm{mab}} / \mathrm{ZnONRs} / \mathrm{CCY}$ immunoelectrode towards absence and presence of cortisol with different concentrations ( $1 \mathrm{fg} / \mathrm{mL}$ to $1 \mu \mathrm{g} / \mathrm{mL})$ and (b) Linear plot of $\mathrm{R}_{\mathrm{ct}} v s$. logarithmic concentrations of cortisol.

For sensing applications, the relative change in EIS data was estimated as it possesses more significant information than absolute values. The BSA/Anti-C $\mathrm{Cab}_{\mathrm{Z}} / \mathrm{ZnONRs} / \mathrm{CCY}$ immunoelectrode was utilized to study the interaction between immobilized Anti- $\mathrm{C}_{\text {mab }}$ and cortisol concentrations from $1 \mathrm{fg}$ to $1 \mu \mathrm{g}$ (Figure. S7). The EIS spectra were recorded using PBS (10 mM, pH 7.0) containing $5 \mathrm{mM} \mathrm{Fe}(\mathrm{CN}) 6^{3 \_}{ }^{14}-$ as a redox probe. The cortisol solutions were prepared in PBS (pH 7.0) to simulate physiological conditions. From Figure. S7 (a), it can be seen clearly in Nyquist spectra that the net impedance values gradually increased with the cortisol concentration ( $1 \mathrm{fg} / \mathrm{mL}$ to $1 \mu \mathrm{g} / \mathrm{mL}$ ). The increase in $R_{c t}$ was attributed to the binding of cortisol to immobilized Anti- $\mathrm{C}_{\text {mab }}$ on the immunoelectrode and by producing an insulating immune-complex that decreases the electron transfer at the electrode interface.

A calibration curve is drawn between logarithmic values of cortisol concentrations and corresponding $R_{c t}$ values. The results showed that a linear increment in Rct values corresponding to the cortisol concentrations ranging from 1 to $1 \mu \mathrm{g}$ with an $\mathrm{R}^{2}$ value of 
0.985 was observed (Figure. S7 (b)). The typical linear regression equation can be given as $\Delta \mathrm{R}_{\text {ct }}(\Omega)=1.889 \mathrm{x}+81.71 \log \mathrm{C}_{\text {cortisol }}(\Omega)$.

Table S1. The comparison of sensing performance of $\mathrm{BSA} / \mathrm{Anti}-\mathrm{C}_{\mathrm{mab}} / \mathrm{ZnONRs} / \mathrm{CCY}$ immunoelectrode with the previous reports towards the detection of cortisol.

\begin{tabular}{|c|c|c|c|c|c|c|}
\hline Sensing Platform & $\begin{array}{l}\text { Sensing } \\
\text { molecule }\end{array}$ & Analyte & Transducers & $\begin{array}{l}\text { Linear } \\
\text { range }\end{array}$ & LOD & Ref. \\
\hline $\begin{array}{l}\text { Anti-Cab/ZnO- } \\
\mathrm{NF} / \mathrm{Au}\end{array}$ & Anti-Cmab & Cortisol & $\mathrm{CV}$ & $\begin{array}{l}1 \mathrm{pM}- \\
100 \mathrm{nM}\end{array}$ & $1 \mathrm{pM}$ & 13 \\
\hline Ag@AgO/PANI & Anti-Cmab & Cortisol & $\mathrm{CV}$ & $\begin{array}{l}1 \mathrm{pM}- \\
1 \mu \mathrm{M}\end{array}$ & $\begin{array}{c}0.64 \\
\mathrm{pM}\end{array}$ & 14 \\
\hline $\begin{array}{l}\text { Antibody/d- } \\
\text { BSA/RGO }\end{array}$ & Anti-Cmab & Cortisol & EIS & $\begin{array}{l}10 \mathrm{pM}- \\
100 \mathrm{nM}\end{array}$ & -- & 15 \\
\hline $\begin{array}{l}\text { MWNT-Cu-PP } \\
\text { Electrode }\end{array}$ & $\begin{array}{l}\text { cortisol } \\
\text { aptamer }\end{array}$ & Cortisol & DPV & $\begin{array}{c}100 \mathrm{pM}- \\
50 \mathrm{nM}\end{array}$ & $10 \mathrm{pM}$ & 16 \\
\hline $\begin{array}{l}\text { EA/Anti- } \\
\mathrm{C}_{\mathrm{ab}} / \mathrm{DTSP} / \mathrm{Au} \\
\text { immunoelectrode }\end{array}$ & Anti- $\mathrm{C}_{\mathrm{mab}}$ & Cortisol & $\mathrm{CV}$ & $\begin{array}{l}10 \mathrm{pM}- \\
100 \mathrm{nM}\end{array}$ & $10 \mathrm{pg}$ & 17 \\
\hline $\begin{array}{l}\text { ZnO thinfilm on } \\
\text { nanoporous } \\
\text { polyamide } \\
\text { membrane }\end{array}$ & Anti- $\mathrm{C}_{\mathrm{mab}}$ & Cortisol & EIS & $\begin{array}{l}1 \mathrm{pg}- \\
100 \mathrm{ng}\end{array}$ & $1 \mathrm{pg}$ & 18 \\
\hline $\begin{array}{l}\text { Magnetic } \\
\text { nanoparticle/Scree } \\
n \text { printed carbon } \\
\text { electrode }\end{array}$ & Anti-Cmab & Cortisol & DPV & $\begin{array}{l}0.005 \text { - } \\
150 \mathrm{ng}\end{array}$ & $3.5 \mathrm{pg}$ & 19 \\
\hline $\begin{array}{l}\text { Au/PANI } \\
\text { nanocomposite }\end{array}$ & Anti- $\mathrm{C}_{\mathrm{mab}}$ & Cortisol & $\mathrm{CV}$ & $\begin{array}{l}1 \mathrm{pM}- \\
100 \mathrm{nM}\end{array}$ & $1 \mathrm{pM}$ & 20 \\
\hline $\begin{array}{l}\text { HRP-Strept-Biotin- } \\
\text { Ag- } \\
\text { Cor/AuNPs/MrGO } \\
\text { /Nafion@GCE }\end{array}$ & Anti-Cmab & Cortisol & DPV & $\begin{array}{c}0.1-1000 \\
\mathrm{ng} / \mathrm{mL}\end{array}$ & $0.05 \mathrm{ng}$ & 21 \\
\hline
\end{tabular}




\begin{tabular}{|c|c|c|c|c|c|c|}
\hline $\begin{array}{l}\text { EA/Anti- } \\
\text { Cab/DTSP- }_{\text {ab }} \\
\text { SAM/IDEs }\end{array}$ & Anti-Cmab & Cortisol & $\mathrm{CV}$ & $\begin{array}{c}10 \mathrm{pg} / \mathrm{mL} \\
-100 \\
\mathrm{ng} / \mathrm{mL}\end{array}$ & $10 \mathrm{pg}$ & 22 \\
\hline $\begin{array}{l}\text { Protein G/DTBP } \\
\text { scaffold/Au } \\
\text { electrode }\end{array}$ & Anti-Cmab & Cortisol & SWV & $\begin{array}{l}0.14- \\
7 \mathrm{nM}\end{array}$ & $16 \mathrm{pg}$ & 23 \\
\hline CNTs & Anti-Cmab & Cortisol & $\begin{array}{c}\text { Chemisresiti } \\
\text { ve }\end{array}$ & $\begin{array}{l}1 \mathrm{pg}- \\
10 \mathrm{ng}\end{array}$ & $1 \mathrm{pg}$ & 24 \\
\hline $\begin{array}{l}\text { Ab@e-RGO } \\
\text { Screen Printed } \\
\text { Electrode }\end{array}$ & Anti-Cmab & Cortisol & $\begin{array}{l}\text { chronoamper } \\
\text { ometric }\end{array}$ & $\begin{array}{l}0.1- \\
200 \mathrm{ng}\end{array}$ & $0.1 \mathrm{ng}$ & 25 \\
\hline $\begin{array}{l}\mathrm{ZnO} / \text { polyamide } \\
\text { substrate }\end{array}$ & Anti- $\mathrm{C}_{\mathrm{mab}}$ & Cortisol & EIS & $\begin{array}{c}0.01-200 \\
\mathrm{mg} / \mathrm{dL}\end{array}$ & $\begin{array}{c}0.1 \\
\mathrm{mg} / \mathrm{dL}\end{array}$ & 26 \\
\hline $\begin{array}{l}\text { MIP-PPy- Screen } \\
\text { Printed carbon } \\
\text { Electrode }\end{array}$ & $\begin{array}{l}\text { Molecular } \\
\text { Imprinted } \\
\text { Polymers }\end{array}$ & Cortisol & $\mathrm{CV}$ & $\begin{array}{l}1 \mathrm{pM}- \\
10 \mu \mathrm{M}\end{array}$ & $1 \mathrm{pM}$ & 27 \\
\hline $\begin{array}{l}\text { MWCNT-CuTPP } \\
\text { modified electrode }\end{array}$ & Anti-Cmab & Cortisol & $\mathrm{CV}$ & $\begin{array}{l}50 \mathrm{fM}- \\
100 \mathrm{nM}\end{array}$ & $50 \mathrm{fM}$ & 28 \\
\hline $\begin{array}{l}\text { BSA/ Anti- } \\
\text { C mab/ZnONRs/CCY }_{\text {enONode }} \\
\text { electrode }\end{array}$ & Anti-C $\mathbf{C}_{\text {mab }}$ & Cortisol & DPV & $\begin{array}{l}1 \mathrm{fg}- \\
1 \mu \mathrm{g}\end{array}$ & $\begin{array}{c}0.098 \\
\text { fg }\end{array}$ & $\begin{array}{c}\text { Present } \\
\text { work }\end{array}$ \\
\hline
\end{tabular}

Table S2. Paired sample t-test

Paired sample t-test

\begin{tabular}{|c|c|}
\hline Mean difference & 1.008 \\
\hline The standard deviation of the mean difference & 1.668 \\
\hline The standard error of the mean difference & 0.0746 \\
\hline $95 \%$ confidence interval & 25.582 to 26.160 \\
\hline test statistic t & -1.311 \\
\hline degrees of freedom (d.f.) & 4 \\
\hline two-tailed probability & p-value $=0.248$ \\
\hline
\end{tabular}




\section{References}

1. Krichershy, O.; Stavan, Correlated Ostwald Ripening in Two Dimensions. J. Phys. Rev. Lett. 1993, 70, 1473-1476.

2. Zhao, Z.; Lei, W.; Zhang, X.; Wang, B.; Jiang, H. ZnO-Based Amperometric Enzyme Biosensors. Sensors 2010, 10, 1216-1231.

3. Wang, J.; Sun, X.; Wei, A.; Lei, Y.; Cai, X.; Li, C.M.; Dong, Z.N. Zinc Oxide Nanocombs Biosensor for Glucose Detection. Appl. Phys. Lett. 2006, 88, 233106 (1-3).

4. Fei, J.; Luo, W.; Huang, J.F.; Ouyang, H.B.; Wang, H.K.; Cao, L.Y. Effect of Hydrothermal Modified Carbon Fiber Through Diels-Alder Reaction and its Reinforced Phenolic Composites. RSC Adv. 2015, 5, 64450-64455.

5. Song, J.; Yuan, Q.; Liu, X.; Wang, D.; Fu, F.; Yang, W. Combination of Nitrogen Plasma Modification and Waterborne Polyurethane Treatment of Carbon Fiber Paper Used for Electric Heating of Wood Floors. BioResources 2015, 10, 5820-5829.

6. Fei, J.; Luo, D.; Huang, J.; Zhang, C.; Duan, X.; Zhang, L. Growth of Aligned ZnO Nanorods on Carbon Fabric and its Composite for Superior Mechanical and Tribological Performance. Surf. Coat. Technol. 2018, 344, 433-440.

7. Thangaraj. R.; Kumar, A.S. Graphitized Mesoporous Carbon Modified Glassy Carbon Electrode for Selective Sensing of Xanthine, Hypoxanthine and Uric Acid. Anal. Methods 2012, 4, 2162-2171.

8. Xing, Q.; Yates, K.; Vogt, C.; Qian, Z.; Frost, M. C.; Zhao, F. Increasing Mechanical Strength of Gelatin Hydrogels by Divalent Metal Ion Removal. Sci. Rep. 2014, 4, 4706.

9. Karabulut, E.; Pettersson, T.; Ankerfors, M.; Wagberg, L. Adhesive Layer-By-Layer Films of Carboxymethylated Cellulose Nanofibril-Dopamine Covalent Bioconjugates Inspired by Marine Mussel Threads. ACS Nano, 2012, 6, 4731-4739.

10. Alwahib, A. A. A.; Kamil, Y. M.; Bakar,M. H.; Noor, A. S. M.; Yaacob, M. H.; Lim, H. N.; Huang, N. M.; Mahdi, M. A. Reduced Graphene Oxide/Maghemite Nanocomposite for Detection of Lead Ions in Water Using Surface Plasmon Resonance. IEEE Photonics 2018, 10, 4801310 . 
11. Ali, A. M.; Mondal, K.; Singh, C.; Malhotra, B. D.; Sharma, A. Anti-Epidermal Growth Factor Receptor Conjugated Mesoporous Zinc Oxide Nanofibers for Breast Cancer Diagnostics. Nanoscale, 2015, 7, 7234-7245.

12. Kelestemur, S.; Altunbek, M.; Culha, M. Influence of EDC/NHS Coupling Chemistry on Stability and Cytotoxicity of ZNO Nanoparticles Modified with Proteins. Appli. Surf. Sci. 2017, 403, 455-463.

13. Vabbina, P.K.; Kaushik, A.; Pokhrel, N.; Bhansali, S.; Pala, N. Electrochemical Cortisol Immunosensors Based on Sonochemically Synthesized Zinc Oxide 1D Nanorods and 2D Nanoflakes. Biosens Bioelectron. 2015, 63, 124-130.

14. Kaushik, A; Vasudev, A; Arya, S.K; Pasha,S.K.; Bhansali, S. Recent Advances in Cortisol Sensing Technologies for Point-of-Care Application. Biosens Bioelectro. 2014, $53,499-512$.

15. Kim, K. S.; Lim, S. R.; Kim, S. E.; Lee, J. Y.; Chung, C. H.; Choe, W. S.; Yoo, P. J. Highly Sensitive and Selective Electrochemical Cortisol Sensor Using Bifunctional Protein Interlayer-Modified Graphene Electrodes. Sens. Actuator B Chem 2017, 242, $1121-1128$.

16. Fernandez, R.E.; Umasankar, Y.; Pandiaraj, M.; Nickel, J.C.; Iwasaki, L.R.; Kawamoto, B.K.; Todoki, K.C.; Scott, J. M.; Bhansali, S. Disposable Aptamer-Sensor Aided by Magnetic Nanoparticles Enrichment for Detection of Salivary Cortisol Variations in Obstructive Sleep Apnea Patients. Sci. Rep. 2017, 7, 17992.

17. Vasudeva, A.; Kaushik, A.; Tomizawa, Y.; Norena, N.; Bhansali, S. An LTCC-Based Microfluidic System for Label-Free, Electrochemical Detection of Cortisol. Sens Actuators B Chem. 2013, 182, 139-146.

18. Munje, R.D.; Muthukumar, S.; Panneer Selvam, A.; Prasad, S. Flexible Nanoporous Tunable Electrical Double Layer Biosensors for Sweat Diagnostics. Sci. Rep. 2015, 5, 14586.

19. Guzmán, M.M.; Eguílaz, M.; Campuzano, S.; Cortés, A.G.; Sedeño, P.Y.; Pingarrón, J.M. Disposable Immunosensor for Cortisol Using Functionalized Magnetic Particles. Analyst 2010, 135, 1926-1933. 
20. Arya, S.K.; Saha, S.; Ramirez-Vickc, J.E.; Gupta, V.; Bhansali, B.; Singh, S.P. Recent Advances in $\mathrm{ZnO}$ Nanostructures and Thin Films for Biosensor Applications: Review. Anal. Chim. Acta 2012, 737, 1-21.

21. Sun, B.; Gou, Y.; Ma, Y.; Zheng, X.; Bai, R.; Attia, A.; Abdelmoaty, A.; Hu, F. Investigate Electrochemical Immunosensor of Cortisol Based on Gold Nanoparticles/Magnetic Functionalized Reduced Graphene Oxide. Biosens. Bioelectron. 2017, 88, 55-62.

22. Pasha, S.K.; Kaushik, A.; Vasudev, A.; Snipes, S.A.; Bhansali, S. Electrochemical Immunosensing of Saliva Cortisol. J. Electrochem. Soc. 2014, 161, B3077-B3082.

23. Liu, X.; Zhao, R.; Mao, W.; Feng, H.; Liu, X.; Wong, D.K.Y. Detection of Cortisol at A Gold Nanoparticle|Protein G-Dtbp-Scaffold Modified Electrochemical Immunosensor. Analyst 2011, 136, 5204-5210.

24. Tlili, C.; Myung, N.V.; Shetty, V.; Mulchandani, A. Label-Free, Chemiresistor Immunosensor for Stress Biomarker Cortisol in Saliva. Biosens. Bioelectron. 2011, 26, $4382-4386$.

25. Tuteja, S.K.; Ormsby, C.; Neethirajan, S. Noninvasive Label-Free Detection of Cortisol and Lactate Using Graphene Embedded Screen-Printed Electrode. Nano Micro Lett. 2018, 10, 41.

26. Munje, R.D.; Muthukumar, S.; Prasad, S.; Lancet-Free and Label-Free Diagnostics of Glucose in Sweat Using Zinc Oxide Based Fexible Bioelectronics. Sens. and Actuators B-chem, 2017, 238, 482-490.

27. Pandiaraj, M.; Pasha, S.K.; Snipes, S.A.; Bhansali, S. A Reusable Electrochemical Biosensor for Monitoring of Small Molecules (Cortisol) Using Molecularly Imprinted Polymers. J. Electrochem. Soc. 2017, 164, B54-B59.

28. Pandiaraj, M.; Fernandez, R.E.; Umasankar, Y.; Gurusamy, M.; Arizaleta, F.; Urizar, G.; Bhansali, S. Salivary Cortisol Analysis using Metalloporphyrins and Multi-Walled Carbon Nanotubes Nanocomposite Functionalized Electrodes. Sens Actuators B Chem. 2018, 274, 47-53. 